\title{
Examination of Organizational Culture Variables in Sports Organizations (Perspective from Turkey)
}

\author{
Serdar Samur (Corresponding author) \\ Department of Sports Management, Sports Science Faculty \\ Istanbul Gedik University, Istanbul, Turkey \\ E-mail: ssamur_2002@yahoo.com
}

Received: April 13, 2021 Accepted: May 13, 2021 Published: May 31, 2021

doi:10.5296/jei.v7i1.18531 URL: https://doi.org/10.5296/jei.v7i1.18531

\begin{abstract}
Organizational stagnation occurs in every system where basic cultural change slows down, and the current situation becomes the usual option until conscious and consistent cultural change initiatives are implemented. It is seen that sports organizations in our country cannot make the desired change in their organizations, although they apply modern management approaches to increase their performance. The study aims to determine the cultural variables and their sub-titles that affect the increase of sports organizations' performance. This research was conducted according to qualitative research methods. In the research, 4 different types of culture emerged as Solidarity and Cooperation, Innovative, Being Competitive, and Emphasis on Hierarchy. It has been determined that these types of culture are similar to Clan, Adhocracy, Marketing,and Hierarchy Culture types defined as dominant cultural differences in Quinn and Cameron's competitive values model.
\end{abstract}

Keywords: Organizational culture, Cultural variables, Transition, Performance

\section{Introduction}

In today's conditions where the technological ecosystem is constantly changing, social life and culture are also changing. Change in social life also triggers organizational change.

In the changing innovative culture, the strong mutual relationship environment that will connect people together will contribute to the spirit of togetherness and the development of the environment of trust. As trust develops in this regard, it will be easier to adapt to innovation and to become a lifestyle of innovation, which will contribute to the positive development of work ethics and the formation of behaviors that facilitate continuous learning. The increase in self-confidence in the individuals of the institution will pave the way for the establishment of a corporate culture that encourages productivity, development, and risk 
taking.

Identifying the dominant character in the current organizational culture will be needed to define the transition to an innovative cultural environment and to manage change.

Many organizational workers and observers now acknowledge that organizational culture has a strong impact on the performance and effectiveness of the organization (Cameron \& Ettington, 1988; Denison, 1990; Trice \& Beyer, 1993).

Organizations are social entities that have a connection with the external environment and are designed as activity systems that are structured and coordinated in advance towards a specific goal (Daft, 2004). Organizational culture is considered as a subculture of society culture. John Van Maanen explains the organizational culture with the information shared by the individuals who constitute the organization, the information exchange between them, and the routine and non-routine activities within the organization.

Organizational culture is a type of culture shaped by organizational practices related to the organizational environment (Oudenhoven, 2001). Organizational culture can be defined as beliefs, attitudes, and values that are shared and relatively stable within an organization (Mwaura et al., 1998). Organizational culture consists of a series of symbols, ceremonies, and myths.

The different cultural power developed by successful companies undertakes the task of creating a common meanings system, expectations, intergenerational basic values and norms, creating a collective identity and loyalty, and enlightening the vision of the future (Trice \& Beyer, 1993).

There are two approaches to define and evaluate the organizational culture. These are the comparative and contingency approach and the approach that takes culture as the organization itself. The comparative and contingency approach is considered as a variable, and organizational culture is considered as a phenomenon that is shaped according to the external environment it is in, and the internal characteristics and relations.

According to the other approach that is affected by anthropology and treats Culture as the Organization Itself, culture is not a variable in the organization, but the organization itself. According to this point of view, organizational culture is examined not only through material data but rather with symbolic, expressive, and intellectual data.

In the literature, the perspective that organizations are culture is more accepted (Cameron \& Quinn, 2011). Within the framework of these approaches, the organizational culture models named below were created and examined by scientists:

- Parsons Model

- B. Schein Model

- Kilmann Model

- Quinn and Cameron Model 
- Byars Model

- $\quad$ Deal and Kennedy Model

- $\quad$ Miles and Snow Model

- Ouchi’s “Z” Culture Model

- Peters and Waterman's Model of Excellence

It has been seen in the results of many studies that the Quinn and Cameron Model is very suitable in defining the variables belonging to the organizational culture. Cameron and Quinn (2017) stated that although many organizations enthusiastically apply New age management approaches and change strategies to manage change, their organizations do not increase their performance. The reason for this is that there are no change in the organization's vital culture - way of thinking, management styles, and approaches to problem-solving, and that they remain the same.

Many studies conducted in the last 10 years show that the most emphasized reason for the failure of companies is the neglect of the organizational culture and the failure to change the organizational culture has affected this. Quinn et al. developed a model called "Competitive Values" that examines the relationship between organizational success and organizational culture. This model is based on empirical analysis of individuals' value judgments for organizational effectiveness.

These authors use the "Organizational Culture Assessment Scale" to evaluate the organizational culture. This scale, which is the most frequently used tool in the world, is based on the competitive values model, which is the most widely used theoretical model to measure organizational culture.

The competitive values model defines the Basic assumptions (dominant characters, organizational bond), Interaction patterns (leadership, employee management), and the direction of the Organization (strategic importance, success criteria) that represent the essence of the culture. These features define 4 different types of culture (Cameron \& Ettington, 1988).

The competitive values model has 2 dimensions that can be defined on two axes, as seen in Figure 1. The first dimension is the effectiveness criterion emphasizing flexibility, initiative, and dynamism; stasis distinguishes it from another criterion that emphasizes order and control. The second dimension distinguishes the effectiveness criterion, which emphasizes intro-orientation, integration, and unity, from the other criterion that emphasizes external orientation, differentiation, and competition (Cameron \& Quinn, 2011). 


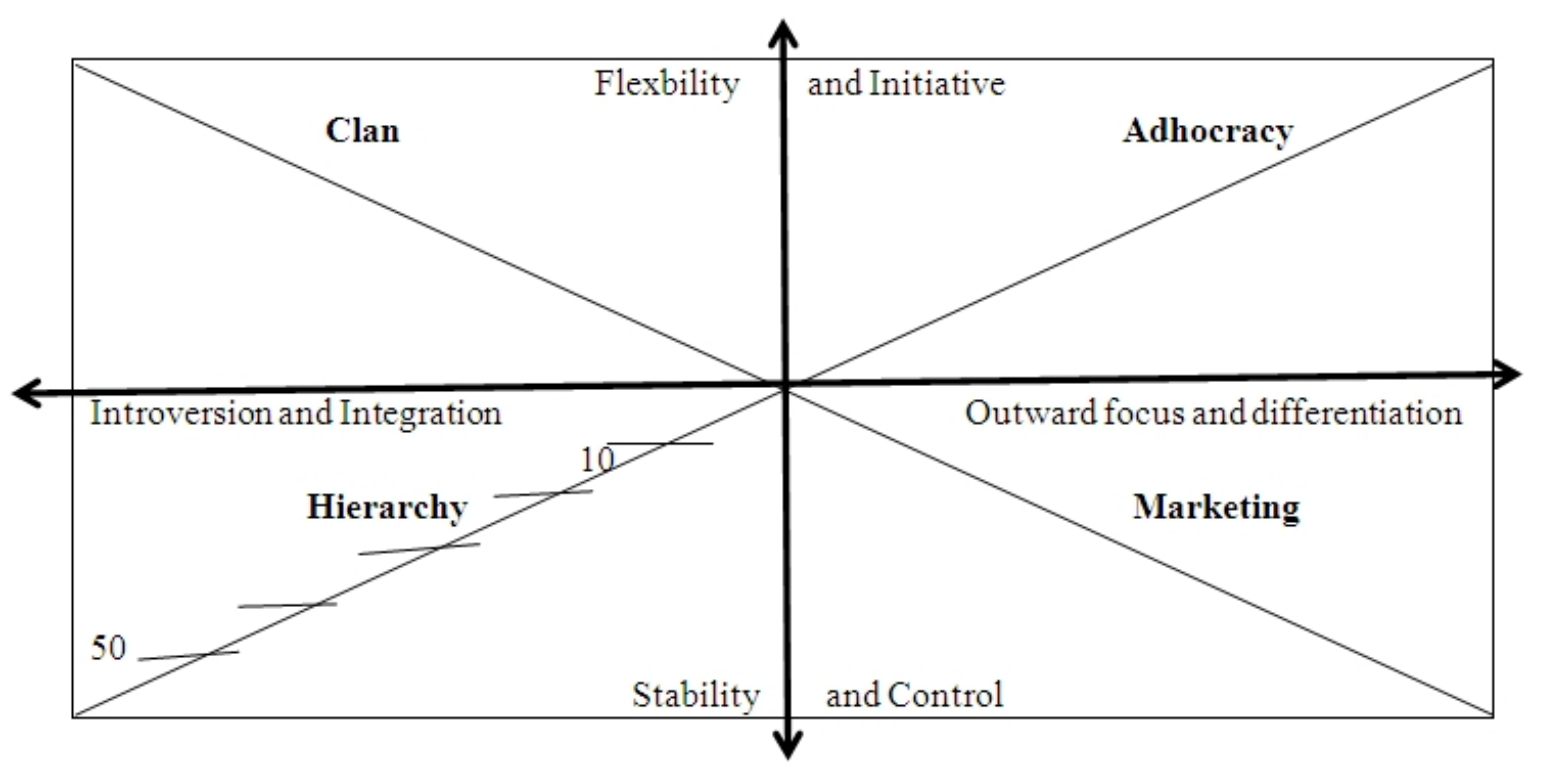

Figure 1. Cameron \& Quinn competitive values model

It turns out that the types of culture emerging with the competitive values model are exactly matched with the main organizational structures developed in organizational science. They also match basic management theories of organizational success, organizational quality approaches, leadership roles, and management skills (Cameron \& Quinn, 2017). Below are the characteristics of 4 different types of culture that are thought to best define the basic values, assumptions, interpretations, and approaches that characterize an organization within the competitive values model.

It turns out that the types of culture emerging with the competitive values model are exactly matched with the main organizational structures developed in organizational science. They also match basic management theories of organizational success, organizational quality approaches, leadership roles, and management skills (Cameron \& Quinn, 2017). Below are the characteristics of 4 different types of culture that are thought to best define the basic values, assumptions, interpretations, and approaches that characterize an organization within the competitive values model.

\subsection{Clan (Cooperation) Culture}

Among the emotions that dominate in clan-type organizations; shared values and goals, consistency, participation, individualism, and a sense of us. Typical characteristics of clan-type companies are teamwork, programs for employee participation, and companies' commitment to employees. Evidence of these characteristics is semi-autonomous work teams that are rewarded based on team success and recruiting and firing their members, quality circles that encourage employees to voice their suggestions on how to improve their own and the company's performance, and an empowering environment (Cameron \& Quinn, 2011).

Some of the basic assumptions of the clan collaboration culture are that the environment can be best managed with teamwork and employee participation, its customers should be 
considered as stakeholders, the organization does business to create a humane working environment, and the main task of management is to empower employees and ensure their participation, commitment,and loyalty. The organization places great emphasis on teamwork participation and consensus (Kotter, 1992).

At the center of the model is the opportunity for people to fail as a team and to compensate for mistakes together. It is expressed as a friendly place where people spontaneously share a lot. Success is defined by the organizational climate and the interest in people (Cameron \& Quinn, 2011).

Leaders within the organization are perceived as mentors or even parents. The organization is kept together with loyalty and tradition. Commitment is high. The organization emphasizes the long-term benefits of individual development with commitment and Moral matters (Schein, 1996).

It refers to organizations that are intrinsic, unity and solidarity are important, organizational commitment is prominent, and informal control processes are dominant. Such organizations are like a family. Organization managers are in the role of parents (Dosoglu-Guner, 2001; Berrio, 2003; Dwyer et al., 2003).

\subsection{Hierarchy (Control) Culture}

This culture is known as Max Weber (1947)'s classic principles of bureaucracy. It includes Rules, Specialization, Qualification, Hierarchy, Division of Labor, Personnel Supremacy, Accountability. These features have been effective in achieving the goal and have been widely used by organizations whose main task is to produce efficient, reliable, trouble-free, predictable outputs (Schein,1999).

People's work is controlled by certain methods. Effective leaders coordinate and organize the organization well. It is important to maintain a smoothly functioning organization. The organization's long-term concerns are stability, predictability,and efficiency. Official policies and rules keep the organization together (Cameron \& Quinn, 2017).

It is shaped between intra-organizational focus and stagnation-control dimensions. These represent mechanical and bureaucratic organizations. Order and rules are important in these cultures. It is clear who will do what and how. It is not allowed to go beyond the standards set for the institution (Schein, 1999).

According to Ouchi (1985), bureaucratic mechanisms tell a person: "do what we tell you, not what you want, because we are paying you for it". Again, according to the author, the bureaucratic mechanism causes alienation, a decrease in the sense of autonomy and purposelessness. Deal and Kennedy (2000) use the definition of "process culture" for this type of culture

\subsection{Market (Competitive) Culture}

It refers to a type of organization that functions as a market. The organization focuses on transactions with external support groups such as suppliers, customers, contractors, rather 
than internal business (Cameron \& Quinn, 2011).

Market Competitive culture operates through economic market mechanisms, competition dynamics,and money exchange. In other words, the main focus of the market is on transactions with other support groups in order to gain a competitive advantage (Deal \& Kennedy, 2000).

The primary objectives of the organization are profitability, end results, resilience to market demands, challenging success targets, and a guaranteed customer base. Naturally, the main values that dominate in market-type organizations are competitiveness and productivity (Cameron \& Quinn, 2017).

Market-type organizations are achieved with a strong emphasis on competitiveness and productivity, externalization, and control. Market competition culture is a result oriented organizational culture (Jones, Jimmieson, \& Griffiths, 2005).

The emphasis on winning is what keeps the organization together. Challenging success goals and objectives are achieved with competitive actions. Success is expressed in terms of market share and spread. It is important to beat everyone in the competition and market leadership (Cameron \& Quinn, 2011).

Market competitiveness refers to organizational environments that emphasize external orientation, competitiveness, and efficiency, but also have a stable and controlling aspect (Berrio, 2003; Pennington et al., 2003).

It is important to have a competitive advantage and market advantage in this cultivar. The success of the organization is evaluated by the increase in market share, the profit obtained, and the tangible outputs (Ouchi, 1987).

Organizational employees are success-oriented in market culture and they focus on planning, performance, and effectiveness (Dosoglu Guner, 2001; Dwyer et al., 2003; Jung, 2003).

Market culture leaders move fast. Leaders show a productive and competitive character. Reputation and success are important in this culture. The power that holds the organization together is the emphasis on winning (Dastmalchian et al., 2000).

\subsection{Adhocracy (Creative) Culture}

In this structure, it is thought that innovative and pioneering initiatives bring success. These types of organizations operate mainly to produce new products and services and to prepare for the future. The main task of management is to promote entrepreneurship, creativity,and cutting-edge technological activities (Jones, Jimmieson, \& Griffiths, 2005).

These types of organizational structures can quickly reshape themselves according to new conditions. Especially in situations of indecision, ambiguity,and information overload, the main task of this type of organization is to encourage flexibility and creativity (Cameron \& Quinn, 2011).

This type of organization is characterized as a dynamic, entrepreneurial and creative 
organization. People take responsibility and take risks. An effective leader is visionary, innovative, and risk oriented (Schein, 1999).

What holds the organization together is the commitment to experiment and innovation. The important thing is to be at the forefront of new information, products, and services. It is important to be prepared for change and tackle new challenges (Jones, Jimmieson, \& Griffiths, 2005).

The long-term emphasis of the organization is on rapid growth and obtaining new resources. The organizational environment is organic, entrepreneurial, flexible, innovative, and creative (Stoica et al., 2004).

The definition of success in the organization is determined as producing unique and original products and services. Cameron and Quinn (2017) Within this structure, employees are encouraged to take initiative and risk personally, to make new inventions, and to have freedom (Dastmalchian et al., 2000; Ataman, 2001).

According to Daft (2004), organizations that need to act quickly to satisfy customers reflect this type of culture when necessary.

As a result, for An organizational change, it is necessary to integrate new age management approaches with approaches to change the culture of the organization. Humans are unaware of their own culture until they come into conflict, meet with a new culture, or appear explicitly through a framework or model.

Therefore, this study will support the efforts of sports organizations to define their own culture type and to change their dominant culture in order to improve their performance.

\section{Methods}

The research was conducted in a qualitative design. Qualitative research and qualitative data collection methods such as observation, interview, and document analysis allow perception and events to be presented in a realistic and holistic way in their natural environment (Yıldırım \& Simsek, 2005).

Limitations: The study of the professional sports club in Turkey has been limited to the selected five clubs.

Participants: 10 managers in the sports club participated in the study.

Development of Data Collection Tool: The data were collected by interviewing techniques with experienced people in the management of the club. Semi-structured questions were asked in the interviews with the participants of the research, and each question was prepared to obtain different data.

Interview Technique and Questions: As the interview technique, Patton's interview form approach was used and 4 open questions were prepared before hand.

Questions in the interview form are as follows: 
- What is important for harmony and commitment in sports clubs?

- What should be done to facilitate change and transformation in sports clubs?

- What characteristics should sports club managers have as a general business skill?

- What kind of management model is needed to increase efficiency in sports clubs?

Data analysis: The data were first written by the researcher and then the data were recorded using content analysis. The answers given by the participants to each question were grouped and interpreted in terms of similarities. In order to increase the reliability of the study, common points of the subjects were determined for the analysis of the data with the support of an expert.

\section{Conclusion}

Organizational culture defines appropriate behavior and relationships, motivates individuals, and offers solutions where there is uncertainty because culture guides the organization in the regulation of knowledge,values, and internal relations, and shows its effect at all levels, visible and invisible.

According to the results of the research, it was seen that there are 4 different types of culture within the organization, such as Solidarity and Cooperation, Innovation, Being Competitive-Competitive, and Paying Attention to Hierarchy, which define the basic assumptions, orientations, and values.

These cultural differences show how things work in the organization, give employees a sense of identity, and imply unwritten and unspoken behavior in the organization.

These variables directly affect the way of doing business of the institution:

- Defining behaviors and relationships deemed appropriate to be implemented within the organization, motivating individuals and offering solutions where there is uncertainty.

- Manages the organization in the regulation of knowledge, values, and internal relations and shows its effect at all levels, visible and invisible.

The characteristics of the leaders who manage the organization will determine which of these culture types that can directly affect the performance of sports organization structures will be chosen as the dominant culture.

In the research; The subjects representing the basic assumptions, orientations, and values within the organization have been examined within the framework of the dominant characteristics, organizational boned, employee management, strategic importance ,and success criteria, and the conclusion is drawn below.

\subsection{Theme 1}

The culture type that emerged regarding the question of what is important for harmony and commitment in the culture of cooperation in sports clubs was found as "Solidarity and Cooperation" culture. In this culture; 
Sports organizations work in partial autonomy as business teams. In the organization, there is an environment in which we, not me, are dominated by emotion, consensus and mutual solidarity are important, and mistakes are eliminated and rewarded as a team.

Synergy is created with the employees in the sense that they are part of the business team. The commitment of the employees to the institution is increased by their spontaneous participation.

In the organization, individuals are given the right to speak and become partners in decisions. In order to increase organizational performance, employees are given authority and responsibility, they are guided and encouraged to take initiative.

Flexibility in the application of the rules is the priority to develop a culture of cooperation. In this way, total quality management develops in cooperation.

The rights of the stakeholders of the club are well defined and sensitive to stakeholder demands and there is a strong communication network between them.

Organizational leaders are open to communication, directing, persuasive, patient,and compassionate, and give confidence to employees. The recruitment processes of the experts who are competent in their jobs are managed very well. Leaders take on the roles of both advisors and family elders.

Success in the organization is defined by the atmosphere of peace in the organizational work environment that puts people in the center. It is believed that giving importance to individual development, strengthening employee loyalty and increasing morale will contribute to corporate success in the long term.

\subsection{Theme 2}

The culture type that emerged regarding the question of what should be done to facilitate change and transformation in Sports Organizations was found to be "An Innovative" culture. In this culture;

In order to adapt to change, there is an innovative management approach in which the entrepreneurial spirit is kept alive within a dynamic, fast-moving, and flexible organizational structure.

New products and services are given importance for continuity. An environment where original ideas will emerge is provided and creativity is encouraged. Success is mostly defined by initiatives that are innovative and different. The organization has advanced technology and this technology is used very well.

Organizational leaders take calculated risks to adapt to change. The leader has a vision and guides the employees in the organization within the framework of common goals.

Within the organizational structure, employees are ready to take responsibility. Organization managers endeavor to develop an innovative understanding in the organization in order to motivate their employees and strengthen corporate belonging. 
In order to make a difference in sportive products and services, the training of employees in the institution is supported and they are provided with new information. Up-to-date information is available and trends are closely followed to facilitate change and transformation. The organization tries to reach new resources and grow by improving the business area and service cycle. In this respect, corporate success is defined by having a diversified range of services.

\subsection{Theme 3}

Regarding the question of what features should be found as a general business skill in Sports Organizations, "The Culture of Being a Competitive" has been found. In this culture;

For the competitive advantage of the organization, it is ensured that the members of the organization are experts in their field. Employees are competitive and goal-oriented.

The Leader carries its competitive edge to its employees to pursue corporate goals and is dedicated to service.

People who are advanced in human and technical skills are worked in the organization. Especially people with high technical skills are employed. In-service training is given importance as a source of technical information.

Close contact is maintained with suppliers and contractors. The support of the fans is trusted to ensure the competitive advantage of the institution. Changes in the sector are closely monitored and competition dynamics are constantly analyzed.

What holds the organization together is the desire to win the championship and success. Success is achieved with competitive actions. Work is result-oriented. Sportive success is the most important criterion in competitor identity. In this respect, leaders are challenging and persistent.

In order to keep profitability sustainable, efforts are made to pursue championships and increase the number of fans.

Market share is increased to stay ahead of the competition. With the recognition of the brand, it is tried to go beyond the city where it is located.

\subsection{Theme 4}

Regarding the question of what kind of a management model is needed to increase efficiency in sports organizations, the culture of "Emphasis on Hierarchy" has been found. In this culture;

The organization has a clear mission that best describes the purpose of its establishment. This mission includes goals, policies, rules, plans, and procedures. Compliance with the rules and consistency is very important. The control and control system works actively.

Work in the organization is done within the framework of rules and procedures. An Internal audit and control system is used to achieve predictable outputs efficiently within the process management. 


\section{Macrothink}

Efforts are made to bring in experts who will contribute to the goals of the organization to the institution. Efficient work is essential. Merit is the most important feature in the institution.

The functional areas are well defined in order to achieve corporate goals. Activities are carried out in a hierarchy. In each function area, how to do things is well determined and the division of labor is done accordingly. An understanding that does not depend on individuals is developed and there is an accountability mechanism.

Leaders ensure correct organization, coordination, and control so that the organization can reach its goals in the shortest way possible. In addition, the leader coordinates the activities very well and tries to correct deviations from the target.

In order to increase productivity in organizations, predictable outputs in a timely manner are achieved at minimum cost. Making decisions centrally reduces risks.

The effort to keep the organization together and ensure continuity is very important. Organizational objectives are achieved in the most economical and efficient manner within a stable structure. Institutional values, policies, and rules are given importance to build a stable structure.

As a result, today, organizational culture plays an important role in companies gaining competitive advantage. Organizational culture presents internal variables that give organization members a different identity and help them to be connected to the organization and are shared by members of the organization.

In today's conditions where the technological ecosystem is constantly changing, one of the most fundamental issues that organizations try to find answers to is how the change and transformation in the organizational culture will be.

It turns out that the types of culture emerging with the competitive values model are exactly matched with the main organizational structures developed in organizational science. They also match basic management theories of organizational success, organizational quality approaches, leadership roles, and management skills

It is believed that the strategic management approaches applied in sports management in our country are not sufficient. Along with these approaches, it will be necessary to review the organizational culture according to the new situation and conditions and to manage this change.

This study was carried out in order to define the cultural variables of sports organizations with a dynamic structure.

In this study, the cultural variables and characteristics defining the organizational culture types were determined and brought to the Table 1 . This study confirms that these variables are very close to the competitive value model. 
Table 1. Organizational culture types and characteristics

\begin{tabular}{|c|c|c|c|c|}
\hline Culture Type & Tendency & Leadership & Effectiveness & Value Creator factors \\
\hline $\begin{array}{l}\text { Solidarity and } \\
\text { Cooperation }\end{array}$ & Collaborator & Directive, persuasive & $\begin{array}{l}\text { Human development } \\
\text { and voluntary } \\
\text { participation in works }\end{array}$ & $\begin{array}{l}\text { Commitment, } \\
\text { Strong Communication, } \\
\text { Development }\end{array}$ \\
\hline Innovative & Creative & Innovative, visionary & $\begin{array}{l}\text { Reaching new } \\
\text { resources with } \\
\text { innovation and vision }\end{array}$ & $\begin{array}{l}\text { Difference-making } \\
\text { output, Agility, } \\
\text { Change-transformation }\end{array}$ \\
\hline $\begin{array}{l}\text { Being a } \\
\text { Competitive }\end{array}$ & $\begin{array}{l}\text { Competition-Competitive } \\
\text { identity }\end{array}$ & $\begin{array}{l}\text { Challenging, } \\
\text { Competitive, } \\
\text { Committed to Service }\end{array}$ & $\begin{array}{l}\text { Competitive } \\
\text { approach and } \\
\text { focus on the fans }\end{array}$ & $\begin{array}{l}\text { Importance to market share } \\
\text { (Increase in the number of } \\
\text { fans), Insist on achieving } \\
\text { goals, Profitability }\end{array}$ \\
\hline $\begin{array}{l}\text { Emphasis on } \\
\text { Hierarchy }\end{array}$ & $\begin{array}{l}\text { Paying attention } \\
\text { to rules, Control } \\
\text { and Supervision }\end{array}$ & $\begin{array}{l}\text { Coordination and } \\
\text { Control, Tracking } \\
\text { and Regulatory }\end{array}$ & $\begin{array}{l}\text { Provides control } \\
\text { and efficiency } \\
\text { in process management }\end{array}$ & $\begin{array}{l}\text { Efficiency, Consistency, } \\
\text { Time importance }\end{array}$ \\
\hline
\end{tabular}

\section{Finding}

Themes, Codes and Participants compiled from research participants on determining the cultural variables of sports clubs are shown in Table 2.

Table 2. Codes and themes in the organizational culture variable

\begin{tabular}{|c|c|c|c|c|}
\hline \multicolumn{2}{|c|}{ Questions } & Code & Them & Participants \\
\hline 1 & $\begin{array}{l}\text { What are the important } \\
\text { things for cohesion and } \\
\text { commitment in a culture of } \\
\text { cooperation in Sports } \\
\text { Organizations? }\end{array}$ & $\begin{array}{l}\text { - Flexibility in the application of the rules, } \\
\text { - Sensitivity to fan and stakeholder demands, } \\
\text { - To give importance to peaceful and harmonious } \\
\text { work within the organization, } \\
\text { - Trying to develop the sense of belonging to the } \\
\text { institution, } \\
\text { - To value the employees of the Organization for } \\
\text { performance increase, to participate in decisions, to } \\
\text { encourage them to take initiative. }\end{array}$ & $\begin{array}{l}\text { Solidarity and } \\
\text { Cooperation }\end{array}$ & $\begin{array}{l}1,2,3,4,5 \\
7,9\end{array}$ \\
\hline 2 & $\begin{array}{l}\text { What should be done to } \\
\text { facilitate change and } \\
\text { transformation in Sports } \\
\text { Organizations? }\end{array}$ & $\begin{array}{l}\text { - To have a dynamic organizational structure and } \\
\text { innovative management approach that can adapt to } \\
\text { change, take risks, } \\
\text { - To give an opportunity to the emergence of } \\
\text { original and creative ideas, }\end{array}$ & Innovative & $\begin{array}{l}2,3,4,5,7 \\
9\end{array}$ \\
\hline
\end{tabular}




\begin{tabular}{|c|c|c|c|c|}
\hline & & $\begin{array}{l}\text { - To follow, own and use technological innovations, } \\
\text { - To correctly direct, develop and share the } \\
\text { decisions of employees in order to reach the vision } \\
\text { of the organization, } \\
\text { - Continuously improving and keeping the business } \\
\text { area and service range up-to-date, }\end{array}$ & & \\
\hline 3 & $\begin{array}{l}\text { Which features should be } \\
\text { found in Sports } \\
\text { Organizations as a general } \\
\text { business skill? }\end{array}$ & $\begin{array}{l}\text { - To have expert individuals to create differentiated } \\
\text { services and products that will provide a } \\
\text { competitive advantage, to develop this with } \\
\text { in-service training, } \\
\text { - To give importance to the conceptual, human, and } \\
\text { technical characteristics of the employees of the } \\
\text { organization, } \\
\text { - Maintaining close contact with stakeholders in } \\
\text { order to react to fan needs in a timely manner, } \\
\text { - To be result-oriented in a way to ensure sportive } \\
\text { success, to keep the desire to win constantly alive, } \\
\text { - To highlight the competitor identity for } \\
\text { competition, to increase the market share. }\end{array}$ & $\begin{array}{l}\text { Being a } \\
\text { Competitive }\end{array}$ & $\begin{array}{l}1,2,3,4,5 \\
6,7,8,9,10\end{array}$ \\
\hline 4 & $\begin{array}{l}\text { What kind of management } \\
\text { model is needed to increase } \\
\text { efficiency in Sports } \\
\text { Organizations? }\end{array}$ & $\begin{array}{l}\text { - To define the aims of the organization very well, } \\
\text { and to have plans, programs and procedures, and } \\
\text { policies to fulfill this } \\
\text { - To construct hierarchy correctly within the } \\
\text { organizational structure, } \\
\text { - To give importance to division of labor, } \\
\text { specialization, and merit, } \\
\text { - To ensure that leaders direct and coordinate } \\
\text { organizational activities very well, } \\
\text { - To have a stable organizational structure to } \\
\text { achieve the desired outcomes, } \\
\text { - To take decisions centrally to reduce risks. }\end{array}$ & $\begin{array}{l}\text { Emphasis on } \\
\text { Hierarchy }\end{array}$ & $\begin{array}{l}1,2,3,4,5 \\
6,7,8,9,10\end{array}$ \\
\hline
\end{tabular}

The statements of the participants in the research and the analysis made according to the claims and opinions of the authors in the field literature are given below.

\subsection{Theme 1: Solidarity and Cooperation}

Participants $(1,5,7,9)$ stated that "Expression of corporate values and goals in sports organizations supports the efforts of employees to achieve these goals" and "Cameron and Quinn (2017)'s claim" shared values and goals, consistency, participation, and sense of us are 
dominant in Clan-type organizations shows paralysis.

Participants (1, 5, 7, 9) stated that "The organization should be structured like semi-independent and autonomous business teams", "Participation in teamwork and acting in consensus should be encouraged and the opportunity should be given to evaluate and solve failures as a team". Cameron and Quinn (2017) argue that "Some of the basic assumptions of clan-type companies include semi-autonomous teamwork (failure as a team and making up for mistakes together), consensus, programs for employee involvement, and companies' commitment to employees". The opinions of the participants support the claims of the authors.

Participants $(2,5,7,9)$ stated that "Managers should strive for the development of emotion, not me", "Individuals should be given the right to speak about achieving corporate goals, and they should be a partner in decisions", "Employees should be included in total quality Management practices". Cameron and Quinn (2017) claim that "Clan type organizations are a friendly place where people share a lot of themselves", "The organization encourages its employees to voice suggestions on how to improve the company's performance", "The organization has an environment that empowers employees within quality circles". The opinions of the participants are close to the claims of the authors.

Participants (1, 2) stated that "In order to develop a culture of cooperation, intra-organizational culture development should be considered as a priority. Stakeholders' rights should be recognized and stakeholder demands should be sensitive", "There should be flexibility in the application of the rules to improve cooperation". Cameron and Quinn (2017) claim that "In clan-type organizations, customers are considered as stakeholders", "The main task of the organization is to empower the employees and to provide a humane working environment in order to ensure their participation and loyalty". The opinions of the participants overlap with the statements of the authors.

Participants: "The duty of the top management of the organization is to value its employees for a peaceful working environment in the organization, to empower them within their job descriptions, to ensure their participation in the decisions to be taken", "In this way, the employee's sense of commitment to the institution will be strengthened and the employee's performance will increase", "Organization leaders should be open to communication, directing, patient and compassionate, and give confidence to employees". Cameron and Quinn (2017) claim that "Clan-type organizations are like a large family", "Leaders are perceived as mentors or even parents, and the organization is held together by loyalty and tradition", "Employee engagement improves". The expressions of the participants are close to the statements of the authors.

Participants $(4,8)$ stated that: "It would be appropriate to create a family environment and to use any kind of social environment for the development of the employee's sense of loyalty to the organization", "Leaders assume the role of advisors in such an environment". Cameron and Quinn (2017) claim that "In clan-type organization, the organization emphasizes the long-term benefits of individual development with commitment and places emphasis on morale". The statements of the participants are close to the claims of the authors. 
Participants $(1,3,4)$ stated that: "Defining the success in the organization with the atmosphere of peace in the work environment that puts people at the center will make it easier to reach other goals", "Giving importance to individual development will strengthen employee loyalty, increase morale and contribute to corporate success in the long term". Cameron and Quinn (2017) claim that "The criteria for success in clan-type organizations are defined by the organizational climate and the interest in people". The statements of the participants support the findings of the authors.

\subsection{Theme 2: Innovative}

Participants $(1,3,5,8)$ stated that "The change in technology needs to differentiate human needs and to have an innovative management approach to respond to this change", "It is important for organizations to have digital technology and to use this technology very well in order to ensure continuity in their work". Kotter (1992) states that "Innovative and pioneering initiatives within the creative culture bring success", "These types of organizations operate mainly to produce new products and services and to prepare for the future", "The main task of the management is to encourage entrepreneurship, creativity and cutting-edge technological activities". The opinions of the participants support the authors' claim.

Participants $(1,3,6)$ stated that "Original ideas and creativity should be encouraged in order to emerge new products and services that will support sustainability". Today, success is defined by more innovative and different initiatives. Kotter (1992) stated that "Organizations with a creative culture type can rapidly reshape according to new conditions", "This organizational structure is one that best suits the conditions that represent the organizational world of the 21 st century, which are overly turbulent and constantly gaining momentum. The statements of the participants are close to the claims of the authors.

Participants $(1,5)$ stated that "In order to keep up with social change, sports organization structures should be structured in a flexible model and react quickly to events", "Creativity should be encouraged to anticipate people's needs". Deal and Kennedy (2000) stated that "The main task of this type of organization is to promote adaptability, flexibility, and creativity in situations of indecision, ambiguity and information overload". Daft (2004) claims that "organizations that need to act quickly to please customers reflect this type of culture when necessary". The opinions of the participants support the claims of the authors.

Participants $(1,4,7)$ state that "Organizations should have a dynamic organizational structure, keep the entrepreneurial spirit warm and give importance to creativity in order to realize change and transformation quickly". Cameron and Quinn (2017) claim that "This type of organization is characterized as a dynamic, entrepreneurial and creative organization". The statements of the participants are parallel to the opinions of the authors.

The participants $(2,5,9)$ state that "The leaders of the organization must take calculated risks to adapt to change, have a vision and guide the employees in the institution within the framework of common goals". Deal and Kennedy (2000) claim that "Effective leader is visionary, innovative and risk-oriented. People take responsibility and take risks". Dastmalchiani (2000), and Ataman (2001) claim that "In this structure, employees are 
encouraged to take initiative and risk personally, to make new inventions and their freedom". The statements of the participants are close to the claims of the authors.

Participants $(3,8,10)$ stated that "Employees should be ready to take responsibility". The motivation of the employees in the organization is research and development and the development of an innovative understanding in the institution, which also strengthens corporate belonging. Jones, Jimmieson, and Griffiths (2005) claim that "What holds the organization together is the commitment to experimentation and innovation". The statements of the participants support the authors' claim.

Participants $(1,3,4,6)$ stated that: "In order to make a difference in products and services, it is necessary to support the training of the employees in the Institution and to ensure that they access new information", "In times of chaos, having up-to-date information and following trends will be an important guide to be ready for change". Schein (1999) claims that "What matters is to be at the forefront of new information, products and services", "It is important to be ready for change and overcome new challenges". The statements of the participants are close to the claims of the authors.

Participants $(2,5,8,9)$ "The organization should try to survive for continuity, by enlarging the business area and service cycle", "It is necessary to build a trustworthy structure in order to reach new resources", "The thing that will define corporate success is to have a diversified range of products and services". Jones, Jimmieson, and Griffiths (2005) stated that "The organization focuses on long-term, rapid growth and obtaining new resources", "The definition of success is to produce unique and original products and services". Stoica (2004) states that "The organization refers to organizational cultural environments that are organic, entrepreneurial, flexible, innovative and creative". The statements of the participants coincide with the claims of the authors.

\subsection{Theme 3: Being a Competitive}

Participants $(2,5,7,9)$ state that "It is important to provide a competitive advantage for the continuity of the organization", "In order to provide a competitive advantage, it is necessary to ensure that the individuals working in the organization structure are experts in their field", "To be goal-oriented, must be productive". Schein (1999) states that "The primary objectives of the organization are profitability, final results, resilience to market demands, challenging success targets and guaranteed customer base", "The main values that are dominant in market-type organizations are naturally competitiveness and productivity". The opinions of the participants support the claims of the authors.

Participants $(2,4,5)$ stated that "Specialists are expected to have the ability to do, perform, and finalize a job", "In order to be competitive, management skills are important in organizations. It is necessary to work with people who have advanced technical skills". Jones, Jimmieson, and Griffiths (2005) state that "Productivity matters. Market-type organizations emphasize external positioning and control for competitiveness and productivity". The opinions of the participants support the authors' claim.

Participants $(1,5,10)$ stated that "Changes in the sector should be closely monitored, 
competition dynamics should be analyzed continuously", "In free market conditions, it is necessary to be in close contact with fans, suppliers, and contractors for competitive advantage". Cameron and Quinn (2017) state that "this type of organization refers to a type of organization that functions as a market", "The organization focuses on transactions with external support groups such as suppliers, customers, contractors within its external environment rather than its internal business", "It operates through market-competitive culture, economic market mechanisms, competition dynamics, and money exchange". Berrio and Pennington (2003) state that "Competition culture refers to organizational environments that emphasize external orientation, competitiveness, and efficiency, but are stable and have a control aspect". The expressions of the participants are close to the opinions of the people.

Participants $(2,5,7,9)$ stated that "Sports clubs are result-oriented structures and Sportive success is the most important criterion", "Leaders are challenging and persistent in this respect", "It is necessary to achieve success with competitive actions, to be ahead of the competition, to increase its market share, to go beyond the city where it is located with brand recognition". Schein (1999) states that "What keeps the organization together is the emphasis on winning", "With competitive actions, challenging success goals and objectives are achieved", "Success is expressed by market share and spreading, outpacing everyone in competition and market leadership is important". The statements of the participants support the claims of the authors.

Participants $(1,5,6,8)$ stated that "What holds the organization together is the desire to win the championship and success". Dosoglu-Guner (2001), and Dwyer and Jung (2003) state that "Organization employees are success-oriented and focus on planning, performance and effectiveness". Dastmalchian (2000) states that "leaders of the market culture act fast and show a productive and competitive character", "Reputation and success are important in this culture", "It is the emphasis on gaining power that holds the organization together". The opinions of the participants support the authors' claim.

Participants $(1,3,4,8)$ stated that "Success in sports is to become an organization that pursues championships, dominate the market in this way and make it sustainable". Schein (1999) claims that "Market-competitive culture is a result-oriented organizational culture", "Leaders here are challenging". Ouchi (1987) claims that "It is important to have competitive advantage and market superiority in this type of culture", "The success of the organization is evaluated by the increase in market share, the profit and concrete outputs". The opinions of the participants are close to the claims of the authors.

\subsection{Theme 4: Emphasize on Hierarchy}

Participants $(1,4,5,7)$ stated that "The aims, policies, plans and procedures should be completed in order to realize the mission of the organization", "Merit should be the most important feature in the institution". Participants $(3,4)$ stated that "the functional areas in the organizational structure should be determined well and division of labor should be done accordingly", "Activities should be carried out in a hierarchy within the organizational structure". Participants $(1,5)$ stated that "an understanding that does not depend on the people based on the institution should be developed and there should be an accountability 
mechanism". Cameron and Quinn (2017) stated that "Max Weber (1947)'s classic principles of bureaucracy take place in the Hierarchy control culture. Among them, Rules, Specialization, Qualification, Hierarchy, Division of Labor, Individuals supremacy, Accountability stand out". The statements of the participants support the claims of the authors.

Participants $(1,2,5,6)$ stated that "Leadership is the most important issue of a sports organization", "Leaders need to organize correctly in a way that the organization can achieve its goals and coordinate its activities very well", "People's work is controlled with certain methods, effective leaders coordinate and organize the organization well". Deal and Kennedy (2000) state that "Order and rules are important in these cultures", "It is clear who will do what and how to do it", "These determined standards are not desired to be exited". Ouchi (1987) states that "bureaucratic mechanisms tell the person: do not what you want, but what we tell you because we are paying you for it". The statements of the participants are close to the claims of the authors.

Participants $(1,3,6,7)$ stated that "The most important issue affecting productivity in organizations is to reach the predictable outputs in process management with minimum cost". Jones, Jimmieson, and Griffiths (2005) state that "This type of organization has been particularly effective in achieving the goal", "They have been widely used by organizations whose main task is to produce efficient, reliable, trouble-free, predictable outputs". Deal and Kennedy (1982) state that "it uses the definition of "process culture' for this type of culture". The statements of the participants support the claims of the authors.

Participants $(3,6,7,10)$ state that "Taking decisions centrally reduces the risks", "It will be appropriate to use the internal audit system to achieve predictable outputs and to do business in the organization within the framework of rules and procedures". Schein (1999) states that "People's work is controlled by certain methods, effective leaders coordinate and organize the organization well", "It is important to maintain a smoothly functioning organization", "The long-term goal of the organization is stability, predictability and efficiency", "Official policies and rules keep the organization together". The statements of the participants are parallel to the claims of the authors.

\section{References}

Akben, A., \& Yesil, S. (2015). The Effects of the Degree of Internationalization on Business Performance: A Field Study. Eurasian Academy of Science Eurasian Business \& Academics Journal, 1, 69-85. https://doi.org/10.17740/eas.econ.2015-V1-03

Alvesson, M. (2002). Understanding Organizational Culture. London: Sage Publications. https://doi.org/10.4135/9781446280072

Ataman, G. (2001). Işletme Yönetimi. Istanbul: Türkmen Kitabevi.

Berrio, A, A. (2003). An Organizational Culture Assessment Using the Competing Values Framework: A Profile of Ohio State University Extension. Journal of Extension, 41(2).

Brown, B. (2003). Employees' Organizational Commitment and Their Perception of 
Supervisors' Relations-Oriented and Task-Oriented Leadership Behaviors ( $\mathrm{PhD}$ Thesis, Virginia Polytechnic Institute and State University, Virginia).

Commeron, K. S., \& Ettington, D. R. (1988). The conceptual Foundation of Organizational Culture. In J. C. Smart (Ed.), Higher Education: Handbook of Theory and Research (p. 4). Norwell, Mass.: Kluwer.

Commeron, K. S., \& Quinn, R. E. (2011). Diagnosing and Changing Organizational Culture: Based on the Competing Values Framework. Personnel Psychology, 59(3), 741-778.

Commeron, K. S., \& Quinn, R. E. (2017). Organizational diagnosis and change (Competitive Values Model). In M. G. Gülhan, \& N. Cemaloğlu (Trans.), Organization Culture (3rd ed.). Ankara, Turkey.

Commeron, K. S., \& Quinn, R. E., \& Degraff, J., \& Thakor, A. (2006). Competing Value Leadership: Creating Value in Organizations. Northhampton, Mass.: Edward Elgar. https://doi.org/10.4337/9781847201560

Culverson, D. (2002). Exploring organizational commitment following radical change: A case study within the Parks Canada Agency. UWSpace.

Daft, R. L. (2004). Organization Theory and Design. Ohio: South Western.

Dastmalchaian, A., Sanghol, L., \& Ignace, N. G. (2002). The Interplay Between Organizational and National Cultures: A Comparison of Organizational Practices in Canada and South Korea Using the Competing Values Framework. International Journal of Human Resource Management, 11(2), 388-412.

Deal, T., \& Kennedy, A. (2002). Corporate Culture: The Rites and Rituals of Corporate Life. Academy of Management Review, 9(2).

Denison, D. R. (1990). Corporate Culture and Organizational Effectiveness. New York: Wiley.

Deshpande, R., \& John, U. F. (2004). Organizational Culture, Market Orientation, Innovativeness, and Firm Performance: An International Research Odyssey. International Journal of Research in Marketing, 21, 3-22. https://doi.org/10.1016/j.ijresmar.2003.04.002

Detert, J. R., \& Schroder, R. G., \& Mauriel, J. J. (2000). A Framework for linking Culture and Improvement Initiative in Organizations. Academy of Management Review, 25, 850-863. https://doi.org/10.5465/amr.2000.3707740

Dosoglu, G. B. (2001). Can Organizational Behavior Explain the Export Intention of Firms? The Effects of Organizational Culture and Ownership Type. International Business Review, 10, 71-89. https://doi.org/10.1016/S0969-5931(00)00040-8

Dwyer, S., Orlando, R., \& Chadwick, K. (2003). Gender Diversity in Management and Firm Performance: The Influence of Growth Orientation and Organizational Culture. Journal of Business Research, 56(12), 1009-1019. https://doi.org/10.1016/S0148-2963(01)00329-0 


\section{Macrothink}

Journal of Educational Issues

ISSN 2377-2263

2021, Vol. 7, No. 1

Handy, C. (1996). Gods of Management: The Changing Work of Organizations. Oxford University Press, UK.

Jones, R. A., Jimieson, N., \& Griffiths, A. (2005). The Impact of Organizational Culture and Reshaping Capabilities on Change Implementation Success: The Mediating Role of Readiness for Change. Journal of Management Studies, 42(2), 361-386. https://doi.org/ 10.1111/j.1467-6486.2005.00500.x

Jung, S. (2003). The Effects of Organizational Culture on Conflict Resolution in Marketing. Journal of American Academy of Business, 3(1/2), 242-246.

Kotter, J. (1992). Corporate Culture and Performance. Free Press.

Lawrence, K., Quinn, R. E., \& Lenk, P. (2009). Behavioral Complexity in Leadership: The psychometric Properties of a New Instrument to Measure Behavioral Repertoire. The Leadership Quarterly, 20(2), 87-102. https://doi.org/10.1016/j.leaqua.2009.01.014

Moores, K., \& Joseph, M. (2000). The Salience of Market, Bureaucratic, and Clan Controls in the Management of Family Firm Transitions: Some Tentative Australian Evidence. Family Business Review, XIII(2), 91-106. https://doi.org/10.1111/j.1741-6248.2000.00091.x

Mwaura, G. M., Sutton, J., \& Roberts, D. (1998). Corporate and National Culture-An Irreconcilable Dilemma for the Hospitality Manager. International Journal of Contemporary Hospitality Management, 10(6), 212-220. https://doi.org/10.1108/09596119810232211

Ouchi, W. G. (1980). Markets, Bureaucracies, and Clans. Administrative Science Quarterly, 25, 129-141. https://doi.org/10.2307/2392231

Ouchi, W. G., \& Alan, L. W. (1985). Organizational Culture. Annual Review of Sociology, 11, 457-483. https://doi.org/10.1146/annurev.so.11.080185.002325

Oudenhoven, J. P. (2001). Do Organizations Reflect National Cultures? A 10-Nation Study. International Journal of Intercultural Relations, 25(1), 89-107. https://doi.org/10.1016/ S0147-1767(00)00044-4

Pennington, P., Christine, T., \& Richard, C. (2003). The Relationship of Leadership Practices to Culture. Journal of Leadership Education, 2(1), 31-44. https://doi.org/10.12806/V2/I1/RF2

Schein, E. (1996). Organizational Culture and Leadership. Jossey-Bass Publishers.

Schein, E. (1999). The Corporate Culture Survival Guide. Jossey Bass Publishers.

Stoica, M., Jianwen, L., \& Karold, W. (2004). Organizational Culture and Patterns of Information Processing: The Case of Small and Medium-Sized Enterprises. Journal of Developmental Entrepreneurship, 9(3), 240-251.

Trice, H. M., \& Beyer, J. M. (1993). The cultures of work organizations. Englewood Cliffs, NJ: Prentice Hall.

Van Der Zee, K. I., \& Van Oudenhoven, J. P. (2001). The Multicultural Personality Questionnaire: Reliability and Validity of Self and Other Ratings of Multicultural 


\section{Macrothink}

Journal of Educational Issues

ISSN 2377-2263

2021, Vol. 7, No. 1

Effectiveness. Journal of Research in Personality, 35, 278-288. https://doi.org/10.1006/ jrpe. 2001.2320

Wilkinns, A. L., \& Quchi, W. G. (1983). Efficient Cultures: Exploring the Relationship between Culture and Organizational Performance. Administrative Science Quarterly, 28, 468-481. https://doi.org/10.2307/2392253

Y1ldırım, A., \& Simsek, H. (2005). Qualitative Research Methods in Social Sciences (p. 366, 5th ed.). Ankara: Seckin Publishing.

\section{Copyright Disclaimer}

Copyright for this article is retained by the author(s), with first publication rights granted to the journal.

This is an open-access article distributed under the terms and conditions of the Creative Commons Attribution license (http://creativecommons.org/licenses/by/3.0/). 